\title{
Distributive Behavior Differences Between In- group and Outgroup and the Influence of Inhibitory Control and Intelligence on Preschoolers' Distributive Behavior
}

\author{
Hye-Weon Byun ${ }^{1}$, Jihyun Sung ${ }^{2}$ \\ Adjunct Professor, Department of Child Psychology and Education, Sungkyunkwan University, Seoul, Korea ${ }^{1}$ \\ Associate Professor, Department of Child Psychology and Education/Convergence Program for Social Innovation, \\ Sungkyunkwan University, Seoul, Korea² \\ 유아의 분배행동의 내·외집단 간 차이와 억제통제 및 지능의 영향 \\ 변혜원 ${ }^{1}$, 성지현 ${ }^{2}$ \\ 성균관대학교 아동·청소년학과 겸임교수, 성균관대학교 아동·청소년학과/소셜이노베이션융합전공/부교수 ${ }^{2}$
}

Objectives: The purpose of this study was to investigate the patterns and characteristics of distributive behavior in preschoolers, influence of inhibitory control and intelligence on the distributive behavior, and associations between them.

Methods: The data was collected through a one-on-one interview experiment with 328 children aged 3-5 years old attending daycare centers and kindergartens. The distributive behavior was measured by modifying the procedure of the dictator game. Children's cognitive and emotional inhibitory control (IC) were assessed using the day-night task and the reverse compensation task respectively. The intelligence was assessed using the K-WPPSI short form test. Pearson's correlation, paired samples $t$-test, one-way ANOVA, McNemar test, multiple regression, and the verification of mediation were performed to analyze the data

Results: First, there were differences among boys in resource allocation according to the type of group (in-group vs. outgroup). That is, boys aged four and five gave more resources to classmates rather than anonymous children. Second, cognitive IC and performance intelligence were associated with distributive behavior towards anonymous children. However, only performance intelligence was related to the children's distributive behavior towards their classmates. Lastly, performance intelligence was completely mediated in the association between cognitive IC and distributive behavior towards anonymous children. Conclusion: We provide empirical evidence that cognitive IC and thinking skills necessary for performance intelligence were related to distributive behavior towards outgroup. In particular, boys aged four and five tended to consider more social relations in distributive behavior. This may be useful information for teaching altruism and sharing in early childhood.

Keywords: distributive behavior, in-group/outgroup, inhibitory control, intelligence, age difference

Corresponding Author: Jihyun Sung, Associate professor, Department of Child Psychology and Education, Sungkyunkwan University, 25-2 Sungkyunkwan-ro, Jongno-gu, Seoul, Korea

E-mail: sungjh@skku.edu (c) The Korean Association of Child Studies

This is an Open Access article distributed under the terms of the Creative Commons Attribution Non-Commercial License (http:// creativecommons.org/licenses/by-nc/4.0) which permits unrestricted noncommercial use, distribution, and reproduction in any medium, provided the original work is properly cited. 


\section{Introduction}

나눔행동에는 절제와 희생이 요구된다. 즉 타인의 이익을 위 해 자신의 물질적 소유의 희생을 필요로 하며, 제한된 자원을 공유해야 하는 상황에서는 자신과 타인의 이익 앞에서 직접적 인 갈등에 놓인다(Birch \& Billman, 1986; Eisenberg-Berg, 1979; Walsh, 1988). 또한 나눔이라는 친사회적 가치에 대해 배운 유 아는 무엇인가를 결정할 때 더 현명하게 선택하고 결정할 수 있는 기준을 가지게 되어(Ryan \& Bohlin, 1999), 나눔교육은 유아의 인성교육을 위해 'how'와 'what' 차원의 답을 제시해주 는 하나의 대안이 될 수 있다(Kang, Kim, Lee, \& Lee, 2007).

타인을 위해 자신의 이익을 포기하며 나눔을 독려하도록 이끄는 사회적 맥락요인은 무엇일까? 학령전 유아들도 받는 사람의 집단정보와 같은 특성이나 자원의 양과 같은 상황 정 보를 고려하여 분배를 결정한다(J. Park \& Jin, 2020; Moore, 2009; Wong \& Nunes, 2003). 자원의 수혜자가 낮선 사람이거 나 친구라고 생각하지 않는 친구보다 자신이 친구라고 생각하 는 대상에게 선호하는 스티커를 더 나누어주고(Moore, 2009), 자신보다 더 어린아이에게 더 많은 장난감 블록을 나누어주려 는 경향을 나타내기도 한다(Wong \& Nunes, 2003). 이는 유아 들도 받는 사람에 따라 자원분배 결정을 다르게 한다는 것을 보여주는 것이다. 이러한 수혜자 고려 현상은 영아들에게서 도 나타난다. 18 개월과 24 개월 영아에게 실험자가 슬픈 표정 으로 손바닥을 위로하여 손을 내밀면서 분배를 요구하였을 때 가 그렇지 않았을 때보다 나누는 행동을 더 많이 하는 모습을 볼 수 있다(Dunfield, Kuhlmeier, O'Connell, \& Kelley, 2011). 또 영유아들의 나눔행동은 내집단에 대한 선호현상으로도 나타 난다. 19 개월 영아들에게 자원(쿠키)의 양과 같은 상황 요소를 고려해 내집단 선호와 공평성 원리 중에서 무엇을 더 우선하 는지 알아보았을 때, 영아들도 분배해야 하는 자원의 양이 모 든 수혜자에게 충분하였을 때는 자원을 나누는 사람이 공평하 게 분배하기를 기대하지만, 분배할 자원의 양이 한정적이었을 때는 분배자가 자신이 속한 내집단 구성원에게만 자원을 공유 하기를 기대하였다(Bian, Sloane, \& Bailargeon, 2018).

학령 전 시기부터 나타나는 이러한 내집단 선호현상은 자 기 자원을 희생하는 자원분배(Dunham, Baron, \& Carey, 2011; Fehr, Bernhard, \& Rockenbach, 2008; Gummerum, Takezawa, \& Keller, 2009; Moore, 2009; Yu, Zhu, \& Leslie, 2016)에서 뿐만 아 니라, 사회관습에 대한 순응과 규칙준수위반 행동에 대한 기 대를 예측할 때에도 내집단 구성원에게는 긍정적인 행동과 외 집단 구성원에게는 부정적인 행동을 연관지어 사고하려는 경
향을 보인다(Liberman, Howard, Vasquez, \& Woodward, 2018). 즉 나이가 어린 영유아도 타인을 돕고, 나누고, 위로하는 행 동을 보이지만 편견과 차별과 같은 사회문제의 기원은 발달 초기부터 발생함을 알 수 있다(Over, 2018). 이러한 현상은 내. 외집단을 구분하는 방법 중 하나인 무작위로 제비뽑기를 하 여 일시적으로 집단을 나누는 '최소집단과제(minimal groups paradigm)'를 통해 구분한 경우에도 나타나는데, 임의로 구분 된 집단에서도 본인이 속한 내집단에게 더 유리하게 분배를 하는 패턴을 보인다(Bigler, Jones, \& Lobliner, 1997; Buttleman \& Böhn, 2014; Dunham et al., 2011; Tajfel, Billig, Bundy, \& Flament, 1971).

선행연구에서 내·외집단을 구분하는 또 다른 방식은 피험 자와 동일하거나 다른 성별, 인종(Renno \& Shutts, 2015), 언어 (Kinzler, Dupoux, \& Spelke, 2007), 소속 기관(Fehr et al., 2008; Yu et al., 2016) 등 개인의 특성을 기반으로 나누거나 형제나 친 구처럼 아는 타인과 낮선 타인(Olson \& Spelke, 2008)과 같은 친숙도를 기반으로 구분하기도 한다. 또한 Cha와 Song (2015) 의 연구 분석에서는 내·외집단으로 구분하지는 않았지만 유아 들의 경우 자신이 분배자원의 수혜자가 되는 경우에는 본인을 '내집단'으로, 본인 이외의 집단은 '외집단'으로 고려하여 유아 자신에게 할당한 스티커 개수와 상대방에게 분배한 스티커 개 수 간의 차이를 나타낼 수 있음을 보고하였다. 그러나 친숙도 를 기반으로 내·외집단을 구분하였을 경우에는 분배의 대상이 친밀하게 아는 상대인지, 그냥 아는 정도인지, 전혀 모르는 대 상인지를 구체적으로 구분하여 내집단에 대한 우호적인 분배 가 일어나는지 검증해볼 필요가 있다. 이는 자원을 분배하려 고 할 때 유아가 친구라고 여기는 대상과 아는데 친구는 아닌 비친구와 낮선 친구를 구분하여 나눔 행위에서 차이를 보이고 있기 때문이다(Birch \& Billman, 1986; Moore, 2009). 또 유아시 기부터 친구라고 생각하는 집단 구성원에게 더 많은 자원을 공유하고(Dunham, 2018; Dunham et al., 2011; Over, 2018; Yu et al., 2016), 자원을 공유해야 하는 인물이 구체적 대상일 경 우에 잘 모르는 아동에 비해 친구에게 더 많은 자원을 분배하 려는(Fehr et al., 2008) 분배행동의 경향성으로 인해, 내·외집단 간 차이를 좀 더 구체적으로 설정하여 알아볼 필요가 있다. 따 라서 본 연구에서는 외집단의 조건을 익명의 친구로, 내집단 의 조건은 유아가 소속된 반에서 좋아하는 친구와 안 좋아하 는 친구로 설정하였다.

또한 독재자 게임 과제를 실시하여 분배행동을 측정한 연 구들에서는 아동의 분배행동의 동기를 타인을 배려하는 마 음, 이타심, 균등한 분배, 친사회적 성향, 문화 등 다양한 요인 
들이 있다고 보고하고 있다(J. Hahn, 2014; Henrich et al., 2004; Hoffman, McCabe, \& Smith, 1996; Kagel, Kim, \& Moser, 1996; Oosterbeek, Sloof, \& van de Kuilen, 2004). 이러한 기존 독재자 게임에서는 익명의 다른 참가자에게, 피험자 본인이 무상으 로 얻은 자원 몇 개를 분배하는지 알아보는 과제들이 다수였 다. 그러나 무상으로 얻은 자원을 타인에게 나누는 것보다 자 신이 보상으로 얻은 자원을 공유하는 것이 진정한 분배행동이 며 결과의 차이가 있음을 밝힌 선행연구(Cheon \& Kim, 2015; Hook \& Cook, 1979)를 고려하여, 본 연구에서는 유아가 보상 을 통해 얻는 자원을 어떻게 공유하는지를 살펴보고자 하였 다. 그리고 독재자 게임 과제를 활용한 분배행동 연구들에서 는 아동의 연령이 높을수록 타인에게 자원분배를 더 많이 할 뿐 아니라(Benenson, Pascoe, \& Radmore, 2007; Gummerum, Hanoch, Keller, Parsons, \& Hummel, 2010; Fehr et al., 2008), 여 아가 남아보다 자원분배를 더 많이 하는 것으로 보고하고 있 다(Gummerum et al., 2010; Harbaugh, Krause, \& Liday, 2003; Takezawa, Gummerum, \& Keller, 2006). 반면, 연령에 따른 차이 를 발견하지 못하거나(Gummerum, Keller, Takezawa, \& Mata, 2008; Takezawa et al., 2006) 남아와 여아 간에 차이가 없다고 (Harbaugh \& Krause, 2000) 보고하는 연구도 있어서 일관적이 지 않다. 그러나 연령에 따라 분배행동의 차이를 보고한 연구 들은 주로 만 7세 이하의 아동을 연구대상에 포함하고 있어서 분배행동의 발달이 만 7세 이전에 이루어지는 것을 알 수 있다 (J. S. Park \& Park, 2013). 따라서 분배행동의 패턴을 알아보기 위해서는 유아시기 분배행동의 경향성을 살펴볼 필요가 있다. 그리고 공통적이지 않지만 자기 자원을 나누는 내집단 선호 분배행동에 관한 연구들에서도 연령과 성차를 보고하고 있다. 여아들과는 달리 남아들은 외집단보다 내집단 구성원들에게 자신의 자원을 더 많이 배분하였고, 자원의 종류가 외집단 구 성원이 선호하지 않는 것이면 오히려 더 분배하려는 부정성을 보이기도 했다(Benozio \& Diesendruck, 2015). 또 Misch, Over 와 Carpenter (2016) 연구에서는 작은 집단 안에서도 4, 5 세 유 아들은 내집단의 비밀을 유지하기 위해 자기 자원을 더 희생 하려는 충성도를 나타냈다. 이러한 내집단 편향 현상은 협력 적 의사결정에 강력한 영향을 미치는 요인이므로(McAuliffel \& Dunham, 2017) 주목할 필요가 있다.

유아기에 나타나는 분배행동의 또 하나의 현상은 공평성이 다(Fehr et al., 2008; Moore, 2009; Wong \& Nunes, 2003). 타인 의 도덕적 책임에 대해 추론을 하는 과정에서 학령전 유아들 은 개인의 내.외집단 정보뿐만 아니라 자원의 양처럼 맥락특 정적인 정보도 같이 사용하는 인지적인 추론을 한다. 그리고
공정성의 원리에 따라 자원을 더 많이 소유한 멤버들이 나누 어주어야 한다고 생각한다(J. Park \& Jin, 2020). Fehr 등(2008) 의 연구에서도 3-8세 아동들은 자신이 속한 기관의 구성원들 과 똑같이 나누기 위하여 개인의 이득을 더 희생하려는 모습 을 발견할 수 있었다. 즉 "자신과 상대방에게 스티커를 얼만큼 나누는 것이 좋을까?”하고 물어보면, “스티커를 공평하게 나 누어 갖는 것이 올바르다.”라고 대답하였다. 그러나 실제로는 7-8세만 공평하게 나누었고, 더 어린 유아들은 이기적으로 분 배하는 양상을 보였다.

즉 유아들의 불공평 혐오(inequality aversion) 선호현상은 7-8세 정도 되어야 이익과 불이익의 불공평을 없애고자 하는 모습을 볼 수 있다(Smith, Blake, \& Harris, 2013). 이러한 불공 평에 대한 혐오 현상은 자신의 사회적 그룹 구성원들을 좋아 하는 편협주의에 의해 강하게 형성된다. 최근 진화론적 관점 에서는 인간의 평등주의와 편협주의가 강한 발달적 뿌리를 가 지고 있으며, 유아기 동안 이타적 분배행동과 편협주의가 동 시 출현하여 함께 진행된다고 예측한다(Fehr et al., 2008). 유아 의 공평 분배 선호와 편협주의는 Moore (2009)의 연구에서도 찾아볼 수 있다. 유아들도 본인의 비용 사용유무와 관계없이 친구에게는 자원을 공평하게 배분하려고 하지만, 자기의 비용 이 들지 않을 때는 비친구보다 낮선 사람에게 더 친사회적으 로 대하고, 자기 비용이 들어갈 때는 비친구와 낮선 사람을 동 일하게 대하였다. 이는 자원분배를 할 때 받는 사람에 대한 유 아들의 평가를 반영하는 것이다.

분배행동의 또 다른 현상은 취학 전 유아들도 분배 결정 시 받는 사람의 특성과 상황 정보를 고려한다(Moore, 2009; Wong $\&$ Nunes, 2003)는 점이다. 상대방의 상황을 고려하는 경향성 은 고차원적인 인지 과정이다. 즉 4세 유아도 이익을 취하기 위한 목적으로 자원을 전략적으로 할당하였는데, 이러한 전략 적 분배는 자발적인 도움과는 부적인 상관관계를 나타낸다. 이와 다르게 6세와 8세는 더 균등하게 자원을 분배하는 모습 을 보인다. 상대가 도움이 필요해도 자신이 즉시 도와줄 수 있 는 상태가 아니면, 분배자원의 수혜자가 부유해도 도움을 주 지 않았다(Kenward, Hellmer, Winter, \& Eriksson, 2015).

실행기능은 목표지향적인 문제해결과정에서 나타나는 사 고와 정서, 반응의 통제를 말하며(Hongwanishkul, Happaney, Lee, \& Zelazo, 2005; Miyake et al., 2000), 실행기능의 다양한 하 위 기능 중 하나인 억제통제는 특히 친사회적 행동과 관련이 있다(Hao, 2017). 억제통제(inhibitory control [IC])는 극히 우 세하고, 간섭하는 반응을 억제하는 능력으로 친사회적 행동에 서 중요한 역할을 한다(Eisenberg, 2010; Gailliot, 2010). 억제통 
제의 하위요인인 인지적 억제통제(cool IC)는 추상적이고 비 맥락적인 상황에서의 문제해결과 관련이 있고, 정의적 억제통 제(hot IC)는 정서적이고 동기적인 상황에서의 문제해결과 관 련이 있다(Zelazo \& Müller, 2011). 따라서 친사회적 행동 중 하 나인 나눔행동은 실행기능의 관여가 필요해 보인다. 즉 불우 한 사람들에게 혜택을 주어야 하는 친사회적 행동목표를 가진 분배행동은 아동들의 요구, 생각, 감정과 갈등을 일으킴으로, 친사회적 경향을 막는 이기심과 충동성이 우선 무시되어야 하 기 때문이다. 더욱이 어린 유아일수록 자신의 이익을 극대화 하려는 욕구와 상대방보다 우위에 있으려는 욕구가 강하기 때 문에(Blake \& Rand, 2010), 자기 자원을 희생해가며 분배를 하 는 행동은 더 어려운 과제일 수 있다. 따라서 더 나은 억제통 제력을 가진 개인은 분배행동과 같은 보다 친사회적인 행동을 보일 가능성이 크고, 친숙한 내집단에게 분배를 할 때 보다 낯 선 외집단에게 분배를 해야할 때 조절기제인 억제통제 기술을 활용할 것으로 예상된다.

Aguilar-Pardo, Martínez-Arias와 Colmenares (2013)는 4-6세 유아의 억제통제가 분배행동과 긍정적인 관련이 있음을 보고 하였고, Paulus 등(2015)도 학령 전 유아의 억제통제와 분배행 동 간의 종단적 연관성을 보고했다. 반면, 학령 전 유아와 초 등학생을 대상으로 한 Liu 등(2016)의 연구와 3-8세 아동을 대 상으로 한 Smith 등(2013)의 연구에서는 억제통제와 분배행 동 간에 유의미한 관계를 밝히지 못했다. 그렇지만 Ciairano, Visu-Petra와 Settanni (2007)는 평균 연령 7, 9, 11세의 초등학생 들 사이에서 억제통제와 협동행동 및 기부행동 사이에 긍정적 인 관계를 보고하였다. 또 $\mathrm{Hao}$ 의 연구(2017)에서는 인지적 억 제통제, 정의적 억제통제는 유아와는 관련이 없었지만, 2학년 6학년과는 관련이 있는 것으로 나타났다. 이처럼 유아기 억제 통제와 분배행동 간의 관계에 대한 선행연구들의 결과가 일관 적이지 않아 본 연구에서는 유아기 억제통제과 분배행동 사이 의 관계에 대해서 알아보고자 하였다.

한편, 실행기능의 하위요인인 억제통제는 만 3-5세 사이 뇌 발달과 함께 두드러지는 발달적 변화를 보이며(Carlson, Davis, \& Leach, 2005), 목표달성을 위해 전략을 짜고, 목표수행에 방 해가 되는 자극이나 충동을 억제해가며 조절하도록 돕는다. 그래서 목표수행과정에서 문제가 발생하면 융통성을 발휘하 여 대안을 생각해 낼 수 있다. 이러한 능력은 지능의 개념과 도 유사하다(S. Park \& Park, 2016). 즉 억제통제는 지능의 하위 영역 중 언어이해, 어휘획득, 비언어성, 일반능력, 인지효율성 과도 유의미한 관련이 있고, 비언어성 지능과 주의 통제 및 주 의 전환과도 관련이 있다(H. J. Kim \& Hong, 2011; H. W. Park
$\&$ Lee, 2013). 지능은 합리적으로 사고하고 해결하는 인지능 력으로 문제해결력, 언어능력, 사회적 지능을 포함하는 개념 (Wechsler, 1999)이다. 따라서 상황판단이나 보상에 대한 판단 과도 관련이 되기 때문에 지능이 높은 유아들이 그렇지 않은 유아들보다 친사회성 수준이 더 높을 수 있다(Han, Shi, Yong, \& Wang, 2012). 친사회적 행동은 유아 스스로 환경을 지각하 고, 외부자극과 통합.조작하는 인지능력에 의해 영향을 받기 때문에 지능은 친사회적 행동의 예측변수가 되어줄 수 있다 (Han et al., 2012). 또한 작업기억, 처리속도와 같은 인지적 효 율성이 낮은 유아일수록 협응문제, 사회적 위축, 지능으로 인 한 문제 발생이 높다. 이는 처리속도가 낮은 유아일수록 분노 조절 문제, 반항성과 같은 품행장애 문제가 높은 것으로 보고 되면서(S. Yeom \& Lee, 2016), 지능과 사회적 행동과의 연관성 이 제기되고 있다.

앞서 기술한 내용을 종합하면 유아의 억제통제가 친사회적 행동인 분배행동에 영향을 미치면서 지능과도 상관이 있으며, 지능은 분배행동에 영향을 미치는 삼자관계에 있다는 것을 알 수 있다. 이는 억제통제와 유사한 기질의 한 요인인 의도적 통 제력(Rothbart \& Derryberry, 1981)도 발달 영역 간의 관계를 다룬 연구에서 의도적 통제가 유아의 사회적 유능성, 공감능 력, 적응 등 사회정서 발달에 미치는 영향에 관하여 일관되게 보고하면서 자기조절력의 근간이 되어 각 발달 영역에 영향을 준다(Bae \& Lim, 2012)고 제시하고 있다. 실제로 유아의 지적 능력은 친사회적 행동과 관련이 있고(Abroms \& Gollin, 1980; Ma \& Leung, 1991), 기질과 사회적 능력 간의 관계(J. Han \& Lee, 2017)나 자기조절력과 친사회성 간의 관계(H.-S. Kim, 2012)에서 인지력과 지능의 매개적 효과에 대해서 언급하고 있다. 따라서 유아의 억제통제와 지능 및 사회적 능력 간의 영 향과 지능 및 친사회성과의 관련성에 대한 연구결과들을 고려 할 때 억제통제와 분배행동 간의 관계에서 지능의 매개적 역 할을 예측해볼 수 있다.

더 나아가 유아기 분배행동과 같은 친사회적 행동은 마음 의 이론, 공감 등의 사회인지능력의 발달로 증가하고(Kwon \& Park, 2013; Singer \& Fehr, 2005), 인지적, 정서적 조망수용과도 관련 있다(Garolyn \& Ha, 2005)고 보았을 때 스스로를 억제조 절하는 사고 능력과 상황을 통합적으로 바라보고, 분석하고, 예측하고, 재구성하는 인지능력들이 요구될 수 있다. 따라서 본 연구에서는 뇌 발달과 함께 두드러지는 억제통제의 발달적 변화를 보이고, 분배행동의 발달패턴을 살펴볼 수 있는 만 3-5 세 유아를 연구대상으로 선정하고자 한다. 더불어 사회맥락적 요인에 따라 만 3-5세 유아의 분배행동 발달에 영향을 미치는 
개인적 요인들을 탐색하여 친사회적 행동 발달의 개인차가 나 타날 수 있는 발달적 기제에 대해 고찰하고자 하였다. 이러한 변인들 간의 영향력과 관련성을 밝히기 위해 다음과 같이 연 구문제를 설정하였다.

\section{연구문제 1}

측정 변인들의 평균, 표준편차, 상관관계는 어떠한가?

\section{연구문제 2}

유아의 분배행동은 내·외집단 분배과제 간에 차이가 있는가?

\section{연구문제 3}

유아의 억제통제와 지능은 내·외집단에 대한 분배행동에 영 향을 미치는가?

\section{연구문제 4}

내·외집단에 대한 분배행동과 유아의 억제통제 간의 관계를 지능이 매개하는가?

\section{Methods}

\section{연구대상}

본 연구는 서울, 경기, 충북 지역에 위치한 어린이집 및 유치원 에 다니고 있는 만 3-5세 유아 328명을 대상으로 하였다. 대상 선정은 유아가 억제통제와 분배행동 과제 수행 시 언어능력으 로 인해 발생되는 문제를 미리 차단하기 위해 한국 웩슬러 유 아지능검사 3판을 간편형으로 표준화한 지능검사(H. W. Park, 2001)를 실시하여서, 경계선 지능(IQ 70) 이상 되는 유아들만 을 대상으로 연구에 참여할 수 있도록 하였다. 연구대상 유아 의 성별은 남아 175 명 $(53.4 \%)$, 여아 153 명(46.6\%)이고, 유아 의 연령은 자료수집이 이루어진 시점을 기준으로 만 3세 72명 (22.0\%), 만 4세 124명(37.8\%), 만 5세 132명(40.2\%)이었다. 전 체 유아 평균 월령은 $58.3(S D=10.75)$ 개월이었고, 만 3세 44.1 $(S D=2.53)$ 개월, 만 4세 $54.9(S D=3,72)$ 개월, 만 5세 $69.2(S D$ $=5.44)$ 개월이며, 출생순위는 첫째가 168 명(52.5\%), 둘째가 105 명(32.8\%) 순이었으며, 주 양육자의 연령은 35-40세 미만 140명(43.8\%), 30-35세 미만 86명(28.8\%), 40-45세 미만 59명 (18.4\%) 순으로 나타났다. 주양육자의 교육 정도는 4년제 대 학교 졸업 140 명 $(44.3 \%)$, 전문대 졸업 87 명(27.5\%), 고졸이하
59명(18.7\%), 대학원 졸업 30명 $(9.5 \%)$ 순이었으며, 가정의 수 입은 400-499만원 이하 66명(20.9\%), 500-599만원 이하 59명 (18.7\%), 700만원 이상 54명(17.1\%), 300-349만원 이하 35명 (11.1\%) 순으로 나타났다.

\section{연구도구}

\section{유아의 분배행동}

독재자 게임은 Benenson 등(2007)과 Gummerum 등(2010)의 연구절차와 Cheon과 $\operatorname{Kim}$ (2015)의 '노력으로 인해 얻은 자원 과제' 절차를 수정하여 사용하였다. 실험에 참가한 유아들은 과제를 하고 난 후에 얻은 보상으로 10 개의 자원을 가상(익명) 의 수령자와 좋아하는 친구.안 좋아하는 친구와 나누어 갖도 록 지시받았다. 유아를 대상으로 한 선행연구(Benenson et al., 2007; Fehr et al., 2008)에서는 독재자 게임의 자원으로 스티커 와 사탕을 주로 사용하였지만, 예비조사시 사탕과 초콜릿보다 스티커에 대한 선호도가 더 높았다. 따라서 스티커의 종류에 대한 선호도를 별도로 조사하여, 유아들이 선호하는 스티커를 독재자 게임의 자원으로 사용하였다. 독재자 게임 과제는 두 가지 형식으로 제시하였으며, 구체적 지시는 다음과 같다. 우 선 첫 번째 과제에서는 익명의 다른 친구들에게 본인이 받은 스티커를 몇 개 나누어 줄지 결정하도록 하였고, 두 번째 과제 에서는 유아가 소속된 반 친구 중에 좋아하는 친구와 안 좋아 하는 친구에게 나누어 줄지, 자신이 가져갈지를 정하도록 지 시하였다. 이때 나누어 준 스티커 개수를 세어 외집단 분배(과 제1), 내집단 분배(과제2)를 각각 기록하였다. 외집단 분배(과 제 1)와 내집단 분배(과제2)의 상관계수는 .75 ( $p$ <.001)로 높 게 나타났다. 측정과제의 지시문은 다음과 같다.

\section{외집단 분배(과제1) $\bigcirc$ 이가 게임을 열심히 참여해서, 선생} 님이 선물을 주려고 해. 이 스티커 멋지지? 스티커가 모두 몇 개인지 세어볼까? 맞아. 이 10 개의 스티커는 모두 $\bigcirc \bigcirc$ 이 꺼 야. 이 스티커는 $\bigcirc \bigcirc$ 가 모두 가져도 되고, 또 친구에게 나눠 주어도 돼. 선생님이 시간이 없어서 다른 친구들에게는 아직 스티커를 나눠 주지 못했거든. 여기 봉투 보이지? $\bigcirc \bigcirc$ 가 갖고 싶은 스티커는 이(파랑) 봉투에 넣고, 친구에게 나눠주고 싶은 스티커는 이(분홍) 봉투에 넣으면 돼. $\bigcirc \bigcirc$ 이가 스티커를 친 구에게 나누어줄지 안줄지, 또 누구에게 나누어줄지는 아무도 몰라. 그럼, 선생님은 다른 일을 좀 하고 있을게(편향성을 줄 이기 위해, 실험자는 도구를 정리하는 시늉을 하였다). 
내집단 분배(과제2) 이 10 개의 스티커는 모두 $\bigcirc \bigcirc$ 이 꺼야. 이 스티커 $\bigcirc \bigcirc$ 이가 모두 가져도 되고, 또 친구에게 나눠 주어도 돼. 선생님이 시간이 없어서 너희 $\bigcirc \bigcirc$ 반에 다른 친구들에게 는 아직 스티커를 나눠 주지 못했어. 여기 봉투 보이지? $\bigcirc \bigcirc$ 이가 갖고 싶은 스티커는 (이)분홍 봉투에 넣고, $\bigcirc \bigcirc$ 이가 좋 아하는 친구에게 주고 싶으면 이(파랑) 봉투에 넣고, 안 좋아 하는 친구에게 주고 싶으면 이(흰색) 봉투에 넣으면 돼. $\bigcirc \bigcirc$ 이가 스티커를 나누어줄지 안줄지, 또 누구에게 나누어줄지는 아무도 몰라. 그럼, 선생님은 다른 일을 좀 하고 있을게(봉투 의 색깔은 무작위로 지정하여 사용하였다).

\section{유아의 억제통제}

유아의 억제통제 측정에서 인지적 억제통제 과제는 낮-밤 과 제(Gerstadt, Hong, \& Diamond, 1994)를, 정의적 억제통제 과 제는 역보상 과제(Carlson et al., 2005)를 사용하였다. 두 과제 는 유아를 대상으로 하는 국내 실행기능 연구에서 많이 사 용하는 도구로(Byun \& Sung, 2018; Kong \& Lim, 2011), 서구 권 유아에 비해 한국 유아들의 실행기능 과제 수행력이 높아 서(Oh \& Lewis, 2008) 본 연구에서는 과제를 단계별로 나누 어 난이도를 조정하였다. 이 규칙은 실행기능 과제의 검사-재 검사 신뢰도를 확인하는 연구(Beck, Schaefer, Pang, \& Carlson, 2011)와 Beck 등(2011)의 연구에서 사용된 차원변경분류과 제(dimensional change card sort)의 통과-실패 기준에 맞춰 낮밤 과제와 역보상 과제를 1 단계와 2 단계로 재구성하여 설계 한 Choi와 Song (2013)의 연구에서 억제통제 과제에 대한 연 령별 수행 능력의 정도를 확인 및 재조정하였다. 모든 과제는 두 단계로 구성되며 1 단계는 12 회 시행, 2 단계는 16 회 시행으 로 총 28 회 시행을 하게 되고, 측정하는 핵심 내용은 동일하되 유아의 수행 정도에 따라 난이도가 향상된다. 1 단계 수행 통과 기준은 유아의 수행률을 고려하여 Beck 등(2011)은 84\%이상, Choi와 Song (2013)은 66\%이상 성공 시 다음 단계로의 수행자 격이 주어지는 것으로 시행하고 있었다. 본 연구의 예비조사 결과 1 단계 과제의 경우 만 4 세는 $60-70 \%$ 이상, 만 5세는 $90 \%$ 이상 수행하였고, 2 단계 과제는 만 3 세, 만 4세, 만 5 세 연령 간 차이를 나타낸다는 것을 확인할 수 있었다. 이는 선행된 연구 와도 일치하는 결과이다. 따라서 1 단계에서 2 단계로의 진입 은 적어도 $50 \%$ 이상, 즉 12 개 중 6 개 이상 맞추어야 2 단계 과제 를 수행할 수 있도록 기준을 정하였다. 점수는 맞으면 1점, 틀 리면 0점, 1 단계 점수 범위는 0-12점, 2단계 점수 범위는 1-16 점, 전체점수 범위는 각각 0-28점으로 점수가 높을수록 억제
통제 수준이 높다는 것을 의미한다.

인지적 억제통제: 낮-밤(Day and night) 과제 Gerstadt 등(1994) 의 Stroop 과제를 만 3-7세 유아용으로 변형하여 억제능력을 측정하도록 고안한 낮-밤 과제를 사용하였다. 유아가 해 그림 과 달 그림 카드를 보며, 1단계에서는 ‘해’ 그림을 보고 ‘밤 또 는 저녁', '달' 그림을 보고 '낮 또는 아침'이라고 말해야 한다. 그다음 2 단계에서는 해와 달 그림 카드에 간헐적으로 붙어 있 는 스티커 여부에 따라 카드에 스티커가 없으면 반대로 말하 고, 카드에 스티커가 있으면 그대로 말해야 한다. 즉 그림과 연 상되는 이름을 억제해야 하는 과제이므로, 과제가 시행되기 전에 그림의 이름이 무엇인지, 해는 언제 볼 수 있는지 달은 언 제 볼 수 있는지를 물어보고 '아침' '저녁' 또는 '낮', '밤'으로 정 확히 명명할 수 있을 때까지 연습하였다. 연습 시행 횟수는 각 연령별로 평균적으로 3-5회 정도로 동일한 원칙을 고수하였 다. 이때 한 번 명명한 것은 일관성 있게 명명해야 맞는 것으로 간주하였다. 즉, 아침이라고 말했으면 계속 아침이라고 말해 야 하고, 낮이라고 했으면 계속 낮이라고 해야 맞는 것으로 하 였다.

정의적 억제통제: 역보상(Less is more) 과제 Carlson 등(2005)이 만 3, 4세 유아를 대상으로 고안한 역보상 과제를 수정하여 사 용하였다. 역보상 과제는 유아가 "얻고 싶은 것을 억제해야 한 다." 는 규칙이 성립해야 하므로 유아에게 '많은 보상(젤리 3 개)'과 '적은 보상(젤리 1개)' 중 어떤 것을 더 선호하는지를 확 인한 후, 선호하는 보상을 일관되게 선택하면 옳은 답으로 간 주하였다. 1 단계에서는 남자 인형이 "어느 쪽 젤리를 갖고 싶 어?” 하고 물으면 유아는 갖고 싶은 것과 반대로 대답을 해야 자신이 선호하는 보상을 가져갈 수 있다. 2 단계에서는 남자 인 형과 여자 인형이 무작위로 제시되며, 남자 인형의 질문에는 갖고 싶은 것과 반대로 대답하고, 여자 인형의 질문에는 갖고 싶은 것을 대답해야 자신이 선호하는 보상을 가져갈 수 있다. 획득된 보상은 잘 보이는 상자에 모을 수 있도록 하여 시각적 인 피드백을 제공하였다. 역보상 과제의 경우, 예비조사에서 연령별 유아들이 선호하는 보상물을 조사한 결과 과일맛 캐 러멜 '마이쮸'에 대한 선호가 높았고, 만 3세 어린 유아도 사물 의 포장만 봐도 인지할 수 있다는 것을 확인한 후 보상물로 결 정하였다. 보상의 개수는 본 예비 연구에서 확인한 결과 3 개도 보상의 효과가 있다고 판단되어서 보상의 수를 최대 3 개로 확 정하였다. 
Table 1

Descriptive Statistics and Correlation Coefficients of Variables

\begin{tabular}{|c|c|c|c|c|c|c|c|c|c|}
\hline Variables & $M(S D)$ & 1 & 2 & 3 & 4 & 5 & 6 & 7 & 8 \\
\hline 1. Task 1 & $2.69(2.75)$ & - & & & & & & & \\
\hline 2. Task 2 & $3.18(2.98)$ & $.75^{* *}$ & - & & & & & & \\
\hline 3. Inhibitory control (IC) & $.73(.26)$ & .08 & .07 & - & & & & & \\
\hline 4. Cool IC & $.80(.26)$ & $.12^{*}$ & .11 & $.76^{* * *}$ & - & & & & \\
\hline 5. Hot IC & $.67(.36)$ & .03 & .02 & $.89^{* * *}$ & $.39^{* * *}$ & - & & & \\
\hline 6. Total IQ & $102.79(15.24)$ & $.15^{* *}$ & .11 & $.30^{* * *}$ & $.32^{* * *}$ & $.21^{* * *}$ & - & & \\
\hline 7. Performance IQ & $105.90(18.25)$ & $.17^{* *}$ & $.15^{* *}$ & $.26^{* * *}$ & $.25^{* * *}$ & $.20^{* * *}$ & $.81^{* * *}$ & - & \\
\hline 8. Verbal IQ & $99.75(14.82)$ & .07 & .03 & $.21^{* * *}$ & $.25^{* * *}$ & $.14^{*}$ & $.78^{* * *}$ & $.27^{* * *}$ & - \\
\hline
\end{tabular}

Note. $N=311$.

${ }^{*} p<.05 .{ }^{* *} p<.01 .{ }^{* * *} p<.001$.

$$
\text { 유아의 지능 }
$$

지능을 측정하기 위해 한국 웩슬러 유아지능검사 K-WPPSI 3 판을 H. W. Park (2001)이 4가지 소검사를 토대로 간편형으 로 개발한 K-WPPSI short form 검사를 사용하였다. K-WPPSI short form은 동작성 요인은 모양맞추기와 토막짜기, 언어성 요인은 이해, 산수의 네 가지 소검사로 구성되어있다. 채점은 소검사별 채점 기준에 의해 이루어지며, 각 소검사별로 원점 수를 구한 다음, 연령별 환산점수 산출표에 의해 소검사별 환 산점수를 산출한다. 그런 후 두 소검사 환산점수의 합계에 $5 / 2$ (2.5)를 곱하여 지능 지수를 추정하게 된다. 검사 제시 순서는 모양맞추기-산수-토막짜기-이해 순으로 동일하게 진행되었 고, 검사 소요시간은 총 20 분 정도이다.

\section{연구절차}

본 연구는 2015년 12월 1일부터 2016년 9월까지 서울, 경기, 충북에 위치한 어린이집 및 유치원 9개 기관에 재원 중인 만 3-5세 유아를 대상으로 실시하였다. 연구자와 유아의 일대일 면접 실험을 통해 측정되었으며, 개별검사 순서는 다음과 같 다. 먼저 연구대상 유아들에게 지능검사를 실시하고, 지능검 사 후 인지적 억제통제, 정의적 억제통제를 측정, 이에 대한 보 상으로 스티커를 제공한 다음 분배행동 과제 1,2 순으로 동일 하게 진행하였다. 검사 시간은 한 유아 당 평균 30-40분 정도 소요되었으며, 유아들의 과제 수행에 방해가 되지 않는 조용 한 교실에서 진행하였다.

\section{자료분석}

수집된 자료는 SPSS 25.0 (IBM Co., Armonk, NY)을 사용하 여 유아의 인구학적 배경과 변인별 기술통계치와 주요 변인 들 간의 상관관계를 알아보기 위하여 Pearson의 적률상관분석 을 실시하였다. 과제유형에 따른 경향을 알아보기 위해, paired samles $t$-test, 일원 피험자내 분산분석과 $\mathrm{McNemar}$ 검증을 실시 하였다. 다음으로는 유아의 억제통제와 지능이 두 가지 상황 에서 유아의 분배행동에 미치는 영향을 알아보기 위하여 다중 회귀분석을 실시하였다. 마지막으로, Jamovi 1.1.9.0을 활용하 여 지능이 유아의 억제통제와 분배행동 간의 관계에서 매개적 역할 하는지 살펴보았고, Bootstrapping 절차를 사용하여 통계 적 유의성을 검증하였다.

\section{Results}

\section{유아의 분배행동과 억제통제 및 지능 간의 관계}

측정 변인들의 평균과 표준편차, 상관관계를 분석하였고, 결 과는 Table 1 과 같다.

외집단 분배행동(과제1)의 평균과 표준편차는 $2.69(S D=$ $2.75)$, 내집단 분배행동(과제2)는 $3.18(S D=2.98)$ 로 낮은 수 준이고, 억제통제의 전체 평균과 표준편차는 $.73(S D=.26)$ 으 로 억제통제의 측정 범위가 0-1점인 것을 감안하면 상위수준 임을 알 수 있다. 본 연구에 참여한 유아 피험자들 지능의 평 균은 102.79 ( $S D=15.24)$ 로 평균(IQ 90-109, K-WPPSI) 정도 
Table 2

Means and Standard Deviations of Distribution of Stickers According to Task Types

\begin{tabular}{|c|c|c|c|c|c|c|c|c|c|}
\hline \multirow[b]{2}{*}{ Type } & \multirow[b]{2}{*}{ Sex } & \multirow[b]{2}{*}{$N$} & \multirow{2}{*}{$\begin{array}{c}\text { Age } 3 \\
M(S D)\end{array}$} & \multirow[b]{2}{*}{$N$} & \multirow{2}{*}{$\begin{array}{c}\text { Age } 4 \\
M(S D)\end{array}$} & \multirow[b]{2}{*}{$N \mathrm{~N}$} & \multirow{2}{*}{$\begin{array}{c}\text { Age } 5 \\
M(S D)\end{array}$} & \multirow[b]{2}{*}{$N$} & \multirow{2}{*}{$\frac{\text { Total }}{M(S D)}$} \\
\hline & & & & & & & & & \\
\hline \multirow{2}{*}{$\begin{array}{l}\text { Task } 1 \\
\text { (Anonymous children) }\end{array}$} & Boys & 38 & $2.13(2.98)$ & 57 & $2.95(2.81)$ & 73 & $3.03(2.41)$ & 168 & $2.80(2.69)$ \\
\hline & Total & 68 & $2.38(3.15)$ & 115 & $2.59(2.75)$ & 128 & $2.95(2.50)$ & 311 & $2.69(2.75)$ \\
\hline $\begin{array}{l}\text { Task } 2 \\
\text { (Like/dislike friends) }\end{array}$ & Boys & 38 & $2.45(3.33)$ & 57 & $3.60(3.05)$ & 73 & $3.82(2.86)$ & 168 & $3.43(3.06)$ \\
\hline
\end{tabular}

Table 3

Comparison by Sex and Age of Children Distributing Stickers According to Task Types

\begin{tabular}{ccccc} 
& Sex & Age 3 & Age 4 & Age 5 \\
Task 1 vs 2 & Boys & $t=-1.28$ & $t=-2.56^{*}$ & $t=-3.40^{* * *}$ \\
\cline { 2 - 5 } & Girls & $t=-.96$ & $t=-.38$ & $t=-1.36$ \\
\hline
\end{tabular}

Note. $N=311$.

${ }^{*} p<.05 .{ }^{* * *} p<.001$.

에 해당하는 집단이다. 또 분배행동과 억제통제, 지능과의 관 계를 Pearson 상관분석을 통해 살펴본 결과, 변인들 간의 상관 계수는 다중공선성을 의심할 수준은 아닌 것으로 확인되었 다. 유아의 외집단에 대한 분배행동(과제 1 )은 인지적 억제통 제 $(r=.12, p<.05)$, 동작성 지능 $(r=.17, p<.01)$ 과 유의한 정적 상관을 갖는 것으로 나타났고, 내집단 분배행동(과제2)은 동 작성 지능 $(r=.15, p<.01)$ 만 유의미한 관련이 있었다. 이는 외 집단에게 분배행동을 할 경우 인지적 억제통제와 동작성 지능 이 높을수록 유아의 분배행동도 높은 것을 알 수 있다. 또한 유 아의 인지적 억제통제는 동작성 지능 $(r=.25, p<.001)$, 언어성 지능 $(r=.25, p<.001)$ 과 정의적 억제통제도 동작성 지능 $(r=$ $.20, p<.001)$, 언어성 지능 $(r=.14, p<.05)$ 과 유의한 정적관계 가 있는 것으로 나타났다. 즉, 유아의 인지적, 정의적 억제통제 력이 높을수록 동작성 지능과 언어성 지능이 모두 높은 것을 알 수 있다.

\section{내·외 집단 과제에 따른 분배행동의 차이 비교}

Table 2 에 제시된 것과 같이 외집단 분배행동(과제 1 )의 전체 평균은 $2.69(S D=2.75)$, 내집단 분배행동(과제2)는 3.18 ( $S D$ $=2.98$ )로 내집단 분배행동(과제2)의 점수가 외집단 분배행동 (과제1)보다 높게 나타났다. 이러한 분배행동의 내.외 집단간 차이는 통계적으로 유의미하였고 $(t=-4.21, p<.001)$, 내·외 집 단간 분배행동의 차이는 만 4 세 남아 $(t=-2.56, p<.05)$, 만 5 세
남아 $(t=-3.40, p<.001)$ 에게서 나타났다(Table 3).

유아들의 자원분배 분포에도 내.외집단에 따라 차이가 있 었다. 4 개 이하 분배는 불공평 분배, 5 개는 공평 분배(Takagishi, Kameshima, Schug, Koizumi, \& Yamagishi, 2010)로, 6개 이 상은 이타적 분배(Cha \& Song, 2015)로 분배형태를 정의한 기 준에 따라 유아들의 분배행동을 살펴보았다(Table 4).

그 결과 집단별로 가장 우세한 분배형태는 외집단에 대한 분배(과제1)의 경우 불공평한 분배, 공평 분배, 이타적 분배 순으로 나타났고, 내집단에 대한 분배(과제2)는 불공평한 분 배, 이타적 분배, 공평 분배 순으로 많이 일어났다. 또한 분배 형태의 비율로는 외집단에서는 $70.5 \%$ 의 유아가 불공평 분배, $16.7 \%$ 의 유아가 공평 분배, $12.9 \%$ 의 유아가 이타적 분배를 보 이는 것으로 나타났고, 내집단에서는 $60.5 \%$ 의 유아가 불공평 분배, $26.0 \%$ 의 유아가 이타적 분배, $13.5 \%$ 의 유아가 공평 분 배를 하였다. 이러한 분배의 차이가 통계적으로 유의미한 것 인지 이항분포를 사용한 McNemar Test 결과 불공평 분배와 이 타적 분배에서 내·외집단에 따라 유의미한 차이가 나타났고 $(N=311, p=.000)$, 공평 분배는 유의미한 차이가 없었다 $(N=$ $311, p=.194)$. 그리고 각 과제 내에서 공평 분배의 차이가 연 령별로 유의미한지 일원 피험자내 분산분석을 실시한 결과 외 집단에 대한 분배(과제1)는 공평 분배에서 연령에 따라 차이 가 나타났으며 $(F(2,308)=3.41, p<.05)$, Scheffe 사후검증 결 과 3 세와 5 세 간에 차이가 있었다(3세 < 5 세, $p<.05$ ). 
Table 4

Comparison by Numbers and Ratio of Distribution of Stickers According to Task Types

\begin{tabular}{|c|c|c|c|c|c|c|c|}
\hline \multirow[b]{3}{*}{ Task } & \multirow[b]{3}{*}{ Age } & \multicolumn{2}{|c|}{ Distribution or not } & \multicolumn{4}{|c|}{ Distribution of distributive behavior } \\
\hline & & 0 piece & 1-10 pieces & $0-4$ pieces & 5 pieces & 6-10 pieces & \\
\hline & & & & Unfair & Fair & Altruistic & Total \\
\hline \multirow{2}{*}{$\begin{array}{l}\text { Task } 1 \\
\text { (Anonymous children) }\end{array}$} & 4 & $53(46.1 \%)$ & $62(53.9 \%)$ & $81(70.4 \%)$ & $19(16.5 \%)$ & $15(13.1 \%)$ & $115(100 \%)$ \\
\hline & 5 & $38(29.7 \%)$ & $90(70.3 \%)$ & 87 (67.9\%) & $28(21.9 \%)$ & $13(10.2 \%)$ & $128(100 \%)$ \\
\hline \multirow{3}{*}{$\begin{array}{l}\text { Task } 2 \\
\text { (Like/dislike friends) }\end{array}$} & 4 & $44(38.3 \%)$ & $71(61.7 \%)$ & $71(61.7 \%)$ & $17(14.8 \%)$ & $27(23.5 \%)$ & $115(100 \%)$ \\
\hline & 5 & $34(26.6 \%)$ & $94(73.4 \%)$ & $71(55.4 \%)$ & $18(14.1 \%)$ & $39(30.5 \%)$ & $128(100 \%)$ \\
\hline & $N(\%)$ & $112(36.0 \%)$ & $199(64 \%)$ & $188(60.5 \%)$ & $42(13.5 \%)$ & $81(26.0 \%)$ & $311(100 \%)$ \\
\hline
\end{tabular}

Note. $N=311$.

Table 5

Effects of Inhibitory Control and Intelligence on Tasks

\begin{tabular}{|c|c|c|c|c|c|c|c|}
\hline DV & IV & $B$ & $\beta$ & S.E. & $t$ & $p$ & Tolerance \\
\hline Task 1 & (Constant) & -.44 & & .96 & -.46 & .64 & \\
\hline (Anonymous children) & Cool IC & .86 & .08 & .62 & 1.38 & .16 & .93 \\
\hline & & \multicolumn{6}{|c|}{$\begin{array}{l}R=.19, R^{2}=.04, \text { Modified } R^{2}=.03 \\
.58(2,307) \cdot p=.01 . \text { Durbin-Watson }=2.10\end{array}$} \\
\hline \multirow{3}{*}{$\begin{array}{l}\text { Task } 2 \\
\text { (Like/dislike friends) }\end{array}$} & (Constant) & .52 & & 1.00 & .51 & .60 & \\
\hline & Performance IQ & .03 & .15 & .00 & 2.68 & .01 & 1.00 \\
\hline & & \multicolumn{6}{|c|}{$\begin{array}{l}R=.15, R^{2}=.02 . \text { Modified } R^{2}=.02 \\
.20(1,309) \cdot p=.01 . \text { Durbin-Watson }=2.09\end{array}$} \\
\hline
\end{tabular}

Note. $N=310$.

\section{내·외 집단에 대한 유아의 분배행동에 미치는 억제통제와 지능의 영향}

유아의 분배행동에 미치는 억제통제와 지능 변인의 영향에 대 해 다중회귀분석을 실시하였고, 결과는 Table 5에 제시하였다.

변인간 상관관계를 고려하여 다중회귀분석을 실시한 결과, 외집단에 대한 분배행동(과제1)에는 동작성 지능만이 분배행 동에 유의한 영향을 미치는 것으로 나타났다 $(\beta=.15, p<.01)$. 동작성 지능은 통계적으로 유의하게 분배행동에 정적 영향을 미치는 것으로 나타났으며, 회귀모형은 $F$ 값이 $5.58(2,307)$ 이 고, 유의수준 .01에서 유의하였고, 회귀식에 대해 $4 \%$ 의 설명력 을 보였다. Durbin-Watson 값은 2.10으로, 0 또는 4에 가깝지 않 기 때문에 잔차들 간에 관계가 없어 회귀모형은 적합하였다.
내집단 분배행동(과제2)에도 동작성 지능만이 분배행동에 유의한 영향을 미치는 것으로 나타났다 $(\beta=.15, p<.01)$. 회귀모 형은 $F$ 값이 $7.20(1,309)$ 이고, 유의수준 .01에서 유의하였고, $2 \%$ 의 설명력을 보였다. Durbin-Watson 값은 2.09로 양호하였다.

\section{내·외 집단에 대한 분배행동과 유아의 억제 통제간 지능의 매개효과 분석}

유아의 억제통제가 지능을 매개로 분배행동에 영향을 미치는 지 매개효과를 검증하였다. 간접효과의 통계적 유의성은 부 트스트래핑(Bootstrapping) 방법을 이용하여 검증하였고, 분배 행동에 미치는 영향력은 직접효과, 간접효과, 총효과로 제시 하였다(Table 6). 
Table 6

Path Estimates and Direct, Indirect, and Total Effects of Variables on Distributive Behavior towards Anonymous Children

\begin{tabular}{|c|c|c|c|c|c|c|c|}
\hline \multirow[t]{2}{*}{ Path \& Effect } & \multirow[b]{2}{*}{$\beta$} & \multirow[b]{2}{*}{ S.E. } & \multicolumn{2}{|c|}{$\begin{array}{l}95 \% \text { Confidence } \\
\text { interval of } \\
\text { indirect effects }\end{array}$} & \multirow[b]{2}{*}{$z$} & \multirow[b]{2}{*}{$p$} & \multirow{2}{*}{$\begin{array}{c}\% \\
\text { mediation }\end{array}$} \\
\hline & & & Lower & Upper & & & \\
\hline Cool IC $\rightarrow$ Distribution & .86 & .50 & -.12 & 1.79 & 1.69 & .09 & \\
\hline Cool IC $\rightarrow$ Performance IQ & 17.86 & 4.13 & 9.18 & 25.97 & 4.32 & .001 & \\
\hline Performance IQ $\rightarrow$ Distribution & .02 & .00 & .00 & .03 & 2.73 & .01 & \\
\hline Indirect effects & .41 & .17 & .07 & .80 & 2.32 & .02 & 32.3 \\
\hline Direct effects & .86 & .50 & -.12 & 1.79 & 1.69 & .09 & 67.7 \\
\hline Total effects & 1.27 & .49 & .29 & 2.22 & 2.54 & .01 & 100.0 \\
\hline
\end{tabular}

Note. $N=311$.

유아의 인지적 억제통제와 외집단 분배행동(과제 1 ) 간의 관계에서 동작성 지능의 매개효과만 유의미하였다. Table 6에 제시된 변인 간 경로분석 결과를 살펴보면, 인지적 억제통제 는 동작성 지능에 유의한 영향을 미치는 것으로 나타났고 $(\beta=$ $17.86, p<.001)$, 동작성 지능은 외집단 분배행동에 유의한 영 향이 있었다 $(\beta=.02, p<.01)$. 반면, 동작성 지능이 투입됨으 로써 인지적 억제통제는 외집단 분배행동(과제 1 )에 유의하게 영향을 미치지 않는 것으로 나타나 $(\beta=.86, p=.09)$, 완전매개 효과가 있음을 확인하였다. 또한 간접효과를 살펴보면, 유아 의 인지적 억제통제가 동작성 지능을 통해 유아의 외집단 분 배행동(과제1)에 간접적으로 영향을 미치고 있으며 $(\beta=.41, p$ $<.02$ ), 간접경로 계수의 $95 \%$ 신뢰구간은 .07 . 80 이고, $32.3 \%$ 정도의 설명력을 보였다. 이를 통해 외집단에 대한 분배행동 (과제1)의 경우, 유아의 인지적 억제통제가 동작성 지능을 매 개로 유아의 분배행동에 영향을 미치는 경로를 확인할 수 있 었다. 반면, 인지적 억제통제와 외집단 분배행동(과제 1 ) 간의 관계에서 언어성 지능과 정의적 억제통제와 외집단 분배행동 (과제1) 간의 관계에서는 매개적 효과가 검증되지 않았다. 또 내집단에 대한 분배행동(과제2)에서도 매개적 효과가 검증되 지 않았다.

\section{Discussion}

본 연구는 만 3-5세 유아들의 내·외 집단의 맥락적 상황에 따 라 분배행동에서 차이를 나타내는지 알아보고자 하였다. 더불 어 유아가 분배행동을 실행하는데 있어서 억제통제와 지능 변
인이 영향을 미치는지 내·외 집단 맥락에 따라 알아보았으며 그 결과는 다음과 같다.

첫째, 유아들은 내·외 집단에 따라 자신의 자원을 분배하 는데 차이를 나타내었다. 즉 익명의 친구보다 나누어야 할 대 상을 구체적으로 떠올리게 할 경우 자신의 자원을 더 많이 나 누어 주었다. 이는 낮선 친구나 자신이 친구라고 생각하지 않 는 대상보다 친구에게 자신의 음식을 더 나누어 주고(Birch \& Billman, 1986), 자원을 공유해야 하는 대상이 익명의 불특정 친구가 아니라 구체적 인물일 경우에 모르는 아동에 비해 친 구에게 더 많은 자원을 분배한다(Fehr et al., 2008)는 선행연구 결과를 지지하고 있다. 이러한 내.외 집단 간 차이는 만 4,5 세 남아에게서 나타났다. 또한 통계적으로 유의미한 차이는 없었 지만 과제 종류와 상관없이 연령이 높아질수록 스티커 배분을 더 많이할 뿐 아니라 여아들보다 더 많이 나누었다. 이는 연령 이 높아질수록 기부행동과 같은 친사회적 행동이 증가한다는 선행연구 결과(Benenson et al., 2007; Blake \& Rand, 2010)와 동 일하고, 3-5세 여아가 남아보다 자기 자원을 더 나눠주었다고 밝힌 Gummerum 등(2010)의 결과와는 다른 결과이다. 과제2 에서는 좋아하는 친구와 안 좋아하는 친구에게 나눠 주는 자 원의 개수에서 차이가 존재했고, 안 좋아하는 친구에게도 자 원을 줄지 안 줄지와 같은 분배의 유무는 남녀 모두 통계적으 로 유의미한 차이가 있었다 $(p<.001)$. 즉 유아들은 좋아하는 친구에게 더 많은 스티커를 나눠주었다. 따라서 이러한 본 연 구결과는 이 시기 남아 여아의 우정개념의 발달적 차이와 유 아시기 분배의 일반적 특성에서 기인된 문제로 해석해볼 수 있으며, 자기 자원을 희생하는 이타적 행동과는 별도의 문제 로 바라볼 필요가 있다. 먼저 유아기는 Damon (1977)의 우정 
개념발달 1 단계에 해당하는 시기로, 유아들은 친구 관계를 물 리적 근거에 따라 물질적인 자원교환, 즉 함께 노는 것, 놀이감 이나 먹을 것 등을 서로 나누는 관계로 이해하고, 자신의 욕구 충족을 우선시 하는 것으로 볼 수 있다. 친구끼리 우정관계에 있는 유아들은 남녀 모두 협력적 놀이와 같은 긍정적인 상호 작용이 빈번하고, 친구에 대해서도 호의적으로 인지한다 $(\mathrm{H}$. L. Moon, 2011). 이러한 유아기 특성은 외집단에 대한 분배행 동(과제1)과 내집단에 대한 분배행동(과제2) 간의 유의미한 차이와 내집단에 대한 분배행동(과제2)에서는 연령과 성별의 차이가 나타나지 않은 본 연구의 결과를 지지한다고 볼 수 있 다. 또한 유아들은 분배에 있어서도 사회적 친분관계에 따라 수혜자의 특성을 고려하는 분배특성이 나타난다고 보고한 연 구(E. Yoo, 1997)와도 동일한 결과이다. 그리고 만 4, 5세 정도 되면 남아와 여아 모두 동성 친구를 더 선호한다. 남아는 남아 들끼리의 집단결속력을 더 선호하고, 여아는 일대일 친구관계 를 더 중요시한다(Hong, 2003). 남아는 자신의 친구 커뮤니티 에 다른 동성 친구를 쉽게 포함시키기도 하고, 친한 친구나 친 밀하지 않은 친구 모두에게 친사회적인 모습을 나타내기도 한 다(Berndt, 1981). 이러한 현상은 남아가 여아보다 더 많은 스 티커를 분배하고, 내·외 집단 간 차이가 외집단에 대한 분배행 동에서 만 4,5 세 남아들에게서 나타난 본 연구결과와 부합되 는 내용이다. 즉 외집단 분배과제에서 4,5 세 남아들이 여아들 보다 더 많은 자원을 분배하며 차이를 보인 것은 연구자가 자 원분배 요청을 했을 때 잘 떠오르지 않는 모르는 친구보다 이 미 형성되어있던 친구 커뮤니티에게 자신의 자원을 더 많이 나누려고 했을 것이다. 반면 여아들은 소수의 친구와만 친구 맺기를 바라는 특성 때문에, 막상 분배를 위해 떠오르는 친구 가 소수여서 내·외집단 간 차이가 없었을 것으로 추측된다.

또한 과제에 따라 자원 분포의 순서에서도 과제 간에 차이 가 나타났다. 즉 내.외집단 모두에서 불공평한 분배가 가장 많 았지만, 내집단은 이타적 분배가 공평한 분배보다 더 많았고, 외집단은 공평한 분배가 이타적 분배보다 더 많았다. 이는 유 아들의 분배행동은 공평한 분배를 선호하지만 실제로는 불공 형 분배가 주로 나타나고, 불공평 분배와 공평한 분배 사이에 서 공평 분배는 내집단 선호와 관련이 있었던 선행연구결과 (Fehr et al., 2008; Smith et al., 2013)를 어느 정도 지지하고 있 다. 이러한 결과를 뒷받침하기 위해 연령별로 공평 분배(자원 을 5 개 나눠주는 분배)에 차이가 나타나는지 알아본 결과 외 집단 분배에서는 연령에 따라 유의미한 차이가 있었고 그 차 이는 3 세와 5 세 간에서 나타났다. 이는 독재자 게임에서 3 세 는 대부분 이기적 분배를 주로 한다는 선행연구 결과(Fehr et al., 2008; Smith et al., 2013)와 동일하며, 유아들은 자기-타인 분배 상황에서 내집단 편향성을 나타낸다는 선행연구 결과 (Olson \& Spelke, 2008)를 지지하는 결과이다. 그리고 과제에 따라 불공평 분배, 공평 분배, 이타적 분배의 비율에서 차이가 있는지 살펴보았는데, 불공평 분배와 이타적 분배에서 내·외 집단 간 분배의 차이가 나타났다. 즉 내집단에서는 이타적 분 배가, 외집단에서는 불공평한 분배가 의미있게 높았다. 이러 한 연구결과로도 만 3-5세 유아들은 대상이 구체적이지 않거 나 낮선(외집단) 대상에게는 자신의 자원을 덜 공유하려 하고, 친숙한 집단의 친구에게는 더 공유하고자 하는 분배의 패턴을 나타내는 것이라고 볼 수 있다.

둘째, 유아의 억제통제와 지능이 분배행동에 미치는 영향 을 과제유형별로 살펴본 결과, 유아의 억제통제의 외집단 분배 행동(과제1)에 대한 회귀적 영향력은 없었지만, 상관관계는 유 의하게 있는 것으로 나타났다. 우선 자기 자원을 희생하는 상 황에서 유아가 맥락을 이해할 수 있는 인지능력과 억제통제와 같은 욕구조절 능력은 유아가 이타적으로 행동하도록 돕는다 (Benozio \& Diesendruck, 2015). 모르는 대상을 위해 자원을 나 눠줘야 하는 부족한 동기와 자기 소유의 스티커를 가져가려는 욕구를 억제하는 능력은 만 3-5세 유아에게는 과도한 인지적 소모과정으로 해석되어 진다. 이는 불공평한 분배가 내집단에 서보다 외집단에서 유의미하게 높게 나타난 결과와도 연결하 여 고려해 볼 수 있다. 이러한 본 연구결과는 4-6세 유아의 억 제통제와 나눔행동 간에 정적인 연관성을 밝힌 선행연구결과 (Aguilar-Pardo et al., 2013; Paulus et al., 2015)와는 일치하고, 학 령전 유아의 분배행동과 억제통제 간에 관계가 나타나지 않았 다고 보고한 Liu 등(2016)의 연구와 Smith 등(2013)의 연구와는 다른 결과이다. 또 억제통제가 분배행동과 밀접한 관련이 있지 만, 유아 시기는 관련이 없고 초등학생 시기에 관련이 있다고 보고한 선행연구 결과(Ciairano et al., 2007; Hao, 2017)와는 달 리 유아기 억제통제와 분배행동은 유의한 관계가 있었다.

지능은 외집단 분배행동(과제1)과 내집단 분배행동(과제 2) 모두에서 동작성 지능만 유의한 관계가 있는 것으로 나타 났다. 동작성 지능은 문제해결력, 운동협응, 시각-운동협응 등의 운동조절능력, 부분-전체 간의 관계 파악능력으로 모호 한 상황에서의 인내심 등의 문제와 연결되고, 갑작스런 상황 에 대한 대처능력도 함께 측정할 수 있다(No, Bak, An, \& Jeon, 2016). 즉 내·외집단에 관계없이 유아가 자신의 자원으로 분배 행동을 하려면 먼저 줄 것인지 안 줄 것인지를 고려하고, 가지 고 있는 한정된 자원에서 자신은 몇 개를 갖고 상대는 몇 개를 나누어줄 것인지를 결정해야 하는데, 이러한 사고기술은 동작 
성 지능에서 측정하는 부분과 전체의 관계 파악능력, 문제해 결력 등이 요구되는 것으로 볼 수 있다. 또한 동작성 지능은 언 어성 지능에 비해 감각운동적 요소, 정서적 요소를 잘 반영하 므로(H. W. Park, Kwak, \& Park, 1996), 두 가지 유형의 지능과 분배행동 간의 관계를 살펴봄으로써 분배행동과 관련한 지능 적 특성에 관한 이해에 도움을 얻을 수 있다. 그리고 유아가 분 배행동 실험과제를 해내기 위해서는 언어이해력뿐 아니라 운 동협응 및 시각-운동협응 등의 운동조절능력 등이 필요하기 때문으로 영향력의 이유를 찾아볼 수 있다. 따라서 동작성 지 능이 분배행동에 영향을 준다는 본 연구의 결과는 유아의 지 적능력이 친사회적 행동과도 관련된다는 선행연구(Abroms \& Gollin, 1980; Han et al., 2012; H.-S. Kim, 2012; Ma \& Leung, 1991)를 지지하는 결과로도 볼 수 있다.

셋째, 억제통제와 분배행동 간의 관계에서 동작성 지능이 두 변인을 매개하는지를 알아본 결과, 외집단 분배행동(과제 1)에서 동작성 지능이 인지적 억제통제와 분배행동 간의 관 계를 완전매개하는 것으로 나타났다. 즉 유아가 익명의 친구 에게 분배행동을 할 때는 동작성 지능 수행 시 필요한 사고기 술을 매개로 사용한다는 것을 알 수 있었다. 우선 동작성 지능 과제에 해당하는 토막짜기나 모양맞추기 활동은 시각처리를 하는 정신능력(Sung et al., 2019)으로 실행기능의 뇌피질 부위 와 근접할 것이라고 알려져 있다(H. Kim \& Hong, 2011; Lee, 2010). 따라서 동작성 지능과제에서 요구하는 사고기술 요소 가 추상적이고 비맥락적인 상황에서의 문제해결과 관련이 있는 인지적 억제통제의 사고기술들을 포함하고 있고, 또 사 회.정서적 반응 및 조절과 관련되는 정의적 억제통제(Byun, 2017)와 분배행동은 직접적인 관련은 없었지만 동작성 지능 과는 관련되므로(Table 1), 변인 간에 매개적 기능을 하였을 것 으로 추측된다. 왜냐하면 구체적으로 떠오르지 않는 낮선 대 상에게 자신의 자원을 나눌지 말지, 누구에게 줄지를 고민해 야 하는 애매한 상황에서는 사고의 유연성, 응용력, 인내심, 대 처능력 등의 더 많은 인지 자원이 요구되기 때문이다. 그리고 또 하나, 독재자 게임 과제를 수행하려면 언어이해 능력뿐 아 니라 과제 수행 시 필요한 운동조절 기술들이 우선 작동해야 하기 때문에 억제통제 기능을 상쇄하고 동작성 지능이 우세한 역할을 한 것으로 추론해 볼 수 있다.

마지막으로 정의적 억제통제(hot IC)와 언어지능은 외집 단 분배행동(과제1)과 내집단 분배행동(과제2)에서 모두 유의 한 관계가 없는 것으로 나타났다. 이는 분배행동 과제와 억제 통제 과제를 실시하기 위해 사전에 언어이해 능력이 갖추어진 유아들을 대상으로 선정하여 실시하였기 때문에 언어지능에
서 차이가 나타나지 않았을 것으로 추정된다. 또한 본 연구에 서 실시한 독재자 게임 과제는 유아가 자원을 나누어야 하는 이유가 타인에 대한 동정심이나 유아의 공감을 자극하여 분배 를 유도하는 방법이 아니기 때문에 정의적 억제통제의 기제인 사회·정서적 반응과 조절 기술의 개입이 요구되지 않았을 것 으로 분석된다.

본 연구는 만 3-5세 유아들의 내.외 집단 구성원에 대한 선 호 차이가 분배행동에 미치는 영향력을 알아본 것과 자신이 보상으로 받은 것을 나누려고 할 때 유아들이 사용하는 억제 통제 및 지능과 같은 인지적 기술들과의 관련성을 살펴보았다 는 점에서 기존 연구들과 차이가 있다. 즉 내·외집단 간의 유 의미한 차이를 통해 만 4,5 세 남자 유아들은 분배행동에서 사 회적 관계를 더 고려하였고, 분배의 대상이 익명일 경우 인지 적 억제통제 기술과 지각적 추리, 통합, 재구성 기술 등의 사고 기술을 사용한다는 것을 보여주는 경험적 증거를 제공하였다. 이는 만 5-9세 아동들의 경우 자신의 보상물을 나눌 때 사회적 친분관계가 분배의 개념에 영향을 주고, 연령과 사회적 친분 관계와 피분배자의 특성에 따라 다른 양상을 고려하여 분배하 였다는 것을 밝힌 선행연구의 결과를 간접적으로 지지하는 결 과이다(Lerner, 1974; Yoo, 1997). 그리고 만 3-5세 사이 뇌 발달 과 더불어 나타나는 억제통제력과 지능 관련한 인지조절 능력 의 발달적 변화의 하나로도 해석해 볼 수 있다.

이와 같은 맥락에서 만 5-6세 유아가 분배행동에서 자신의 이익을 극대화할 수 있는 상황인지에 따라 분배행동에서 차이 가 나타났다(Cha \& Song, 2015)는 결과는 어린 유아도 분배행 동을 하는데 있어서 인지적 기술을 사용하여 분배를 결정한다 는 것을 보여주는 예시라고 말할 수 있다. 그러나 이러한 인지 적 기술들이 분배행동을 설명하는 전적인 요인이 될 수 없다. 즉 유아들이 다른 사람의 의도와 감정을 잘 파악하고 이해할 수록 더 이타적으로 행동하는 것으로 나타났지만, 이러한 관 련성은 의도조망수용보다 정서조망수용에서 더 높았다(J. S. Park \& Park, 2013). 감정에 대한 이해와 추론이 다른 사람의 의 도보다 이타적 행동에 더 중요함을 알 수 있다. 따라서 추후 연 구에서는 유아기 분배행동의 심리적 특성에서 인지적 차원과 정서적 차원에서의 발달기제를 동시에 알아볼 수 있는 방안을 고려해보아야 한다.

본 연구에서 실시한 독재자 게임은 이타성의 여러 요소 중 에서 분배행동만을 다루었기 때문에 유아의 이타성의 정도를 알아보기에는 부족함이 있고, 친사회성과 관련이 없었다는 초 등대상 연구보고도 있으므로(Cheon \& Kim, 2015) 연구해석 에 주의를 요한다. 이는 다양한 이타성의 요인을 평가하는 척 
도와 다면적 평가를 통해 알아보아야 할 것이고, 차후 실험절 차의 보완이 필요하다. 즉 유사한 과제를 연속적으로 실시해 서 성인 실험자가 타인에게 분배를 강조하였다고 생각해서 두 번째 과제에 더 스티커를 할당했을 가능성도 간과할 수 없다.

이러한 제한점에도 불구하고 본 연구는 유아기 분배행동의 독특한 발달패턴과 억제통제력 및 지능과 같은 인지적 자원이 미치는 영향력, 더 나아가 분배행동에서 인지 영역, 사회성 발 달 영역 간의 연관성을 검증하였다. 즉 분배하려는 대상이 친 근한 내집단 구성원이고, 유아가 분배할 대상을 구체적으로 인지하고 있을 경우에 이타적 분배를 할 가능성이 더 높다. 또 한 억제통제와 같은 인지적 자원의 영향력은 분배행동시 통제 와 조절 기술이 필요하여 훈련이 요구됨을 시사한다. 이는 유 아의 분배행동의 습관화를 위해 의미있는 타인에 대한 모델링 뿐 아니라 인지적 차원의 독려가 이후 성인기에 사회 기부행 동의 증가를 예견하는 만큼, 향후 유아기 이타성 교육 지도 시 효율적인 중재방안 마련과 유용한 정보, 나눔 및 기부교육 프 로그램 개발에 기초자료를 제공할 수 있을 것이다.

\section{Notes}

This article was presented at the 2020 Annual Fall Conference of the Korean Association of Child Studies.

\section{Conflict of Interest}

No potential conflict of interest relevant to this article was reported.

\section{Ethics Statement}

All procedures of this research were reviewed by IRB (201-509003-003).

\section{References}

\section{In English}

Abroms, K. I., \& Gollin, J. B. (1980). Developmental study of gifted preschool children and measures of psychosocial giftedness. Retrieved from ERIC database. (EJ227922)

Aguilar-Pardo, D., Martínez-Arias, R., \& Colmenares, F. (2013). The role of inhibition in young children's altruistic behaviour. Cognitive Processing, 14, 301-307. doi:10.1007/ s10339-013-0552-6

Beck, D. M., Schaefer, C., Pang, K., \& Carlson, S. M. (2011). Executive function in preschool children: Test-retest reliability. Journal of Cognition and Development, 12(2), 169-193. doi:10.1080/15248372.2011.563485

Benenson, J. F., Pascoe, J., \& Radmore, N. (2007). Children's altruistic behavior in the dictator game. Evolution and Human Behavior, 28, 168-175. doi:10.1016/j.evolhumbehav.2006.10.003

Benozio, A., \& Diesendruck, G. (2015). Parochialism in preschool boys' resource allocation. Evolution and Human Behavior, 36(4), 256-264. doi:10.1016/j.evolhumbehav.2014.12.002

Berndt, T. J. (1981). Age changes and changes over time in prosocial intention and behavior between friend. Developmental Psychology, 17(4), 408-416. doi:10.1037/0012-1649.17.4.408

Bian, L., Sloane, S., \& Baillargeon, R. (2018). Infants expect ingroup support to override fairness when resources are limited. Proceedings of the National Academy of Sciences, 115(11), 2705-2710. doi:10.1073/pnas.1719445115

Bigler, R. S., Jones, L. C., \& Lobliner, D. B. (1997). Social categorization and the formation of intergroup attitudes in children. Child Development, 68(3), 530-543. doi:10.1111/ j.1467-8624.1997.tb01956.x

Birch, L. L., \& Billman, J. (1986). Preschool children's food sharing with friends and acquaintances. Child Development, 57(2), 387-395. doi:10.2307/1130594

Blake, P. R., \& Rand, D. G. (2010). Currency value moderates equity preference among young children. Evolution and Human Behavior, 31(3), 210-218. doi:10.1016/ j.evolhumbehav.2009.06.012

Buttelmann, D., \& Böhm, R. (2014). The ontogeny of the motivation that underlies in-group bias. Psychological Science, 25(4), 921-927. doi:10.1177/0956797613516802

Carlson, S. M., Davis, A. C., \& Leach, J. G. (2005). Less is more: Executive function and symbolic representation in preschool children. Psychological Science, 16(8), 609-616. doi:10.1111/j.1467-9280.2005.01583.x

Ciairano, S., Visu-Petra, L., \& Settanni, M. (2007). Executive inhibitory control and cooperative behavior during early school years: A follow-up study. Journal of Abnormal Child Psychology, 35, 335-345. doi:10.1007/s10802-006-9094-z

Damon, W. (1977). The social world of the child. San Francisco, CA: Jossey-Bass.

Dunfield, K., Kuhlmeier, V. A., O’Connell, L., \& Kelley, E. (2011). Examining the diversity of prosocial behavior: Helping, sharing, and comforting in infancy. Infancy, 16(3), $227-$ 
247. doi:10.1111/j.1532-7078.2010.00041.x

Dunham, Y. (2018). Intergroup cognition. The International Encyclopedia of Anthropology, 1-8. doi:10.1002/9781118924396.wbiea1767

Dunham, Y., Baron, A. S., \& Carey, S. (2011). Consequences of "minimal" group affiliations in children. Child Development, 82(3), 793-811. doi:10.1111/j.1467-8624.2011.01577.x

Eisenberg, N. (2010). Empathy-related responding: Links with self-regulation, moral judgment, and moral behavior. In M. Mikulincer \& P. R. Shaver (Eds.), Prosocial motives, emotions, and behavior: The better angels of our nature (pp. 129-148). Washington, D.C.: American Psychological Association.

Eisenberg-Berg, N. (1979). Development of children's prosocial moral judgment. Developmental Psychology, 15(2), 128-137. doi:10.1037/0012-1649.15.2.128

Fehr, E., Bernhard, H., \& Rockenbach, B. (2008). Egalitarianism in young children. Nature, 454, 1079-1084. doi:10.1038/ nature07155

Gailliot, M. T. (2010). The effortful and energy-demanding nature of prosocial behavior. In M. Mikulincer \& P. R. Shaver (Eds.), Prosocial motives, emotions, and behavior: The better angels of our nature (pp. 169-180). Washington, D.C.: American Psychological Association.

Gerstadt, C. L., Hong, Y. J., \& Diamond, A. (1994). The relationship between cognition and action: Performance of children 312-7 years old on a stroop-like day-night test. Cognition, 53(2), 129-153. doi:10.1016/00100277(94)90068-X

Gummerum, M., Keller, M., Takezawa, M., \& Mata, J. (2008). To give or not to give: Children's and adolescents' sharing and moral negotiations in economic decision situations. Child Development, 79(3), 562-576. doi: 10.1111/j.14678624.2008.01143.x

Gummerum, M., Takezawa, M., \& Keller, M. (2009). The influence of social category and reciprocity on adults' and children's altruistic behavior. Evolutionary Psychology, 7(2), 295-316. doi:10.1177/147470490900700212

Gummerum, M., Hanoch, Y., Keller, M., Parsons, K., \& Hummel, A. (2010). Preschoolers' allocations in the dictator game: The role of moral emotions. Journal of Economic Psychology, 31(1), 25-34. doi:10.1016/j.joep.2009.09.002

Han, R., Shi, J., Yong, W., \& Wang, W. (2012). Intelligence and prosocial behavior: Do smart children really act nice? Current Psychology, 31(1), 88-101. doi:10.1007/s12144012-9133-6

Hao, J. (2017). Do children with better inhibitory control donate more? differentiating between early and middle childhood and cool and hot inhibitory control. Frontiers in Psychology, 8(2182), 1-9. doi:10.3389/fpsyg.2017.02182

Harbaugh, W. T., Krause, K., \& Liday, S. J. (2003). Bargaining by children (Report No. C70 D10 D63). Retrieved from University of Oregon Economics Working Paper website: https://econpapers.repec.org/paper/oreuoecwp/2002-04. htm

Harbaugh, W. T., \& Krause, K. (2000). “Children's altruism in public good and dictator experiments." Economic Inquiry, 38(1), 95-109. doi:10.1111/j.1465-7295.2000.tb00006.x

Henrich, J., Boyd, R., Bowles, S., Camerer, C., Fehr, E., \& Gintis, H. (2004). Foundations of human sociality: Economic experiments and ethnographic evidence from fifteen smallscale societies. Oxford, England: Oxford University Press.

Hoffman, E., McCabe, K., \& Smith, V. L. (1996). Social distance and other-regarding behavior in dictator games. The American Economic Review, 86(3), 653-660. https://www. jstor.org/stable/2118218

Hongwanishkul, D., Happaney, K. R., Lee, W. S. C., \& Zelazo, P. D. (2005). Assessment of hot and cool executive function in young children: Age-related changes and individual differences. Developmental Neuropsychology, 28(2), 617-644. doi:10.1207/s15326942dn2802_4

Hook, J. G., \& Cook, T. D. (1979). Equity theory and the cognitive ability of children. Psychological Bulletin, 86(3), 429-445. doi:10.1037/0033-2909.86.3.429

Kagel, J. H., Kim, C., \& Moser, D. (1996). Fairness in ultimatum games with asymmetric information and asymmetric payoffs. Games and Economic Behavior, 13(1), 100-110. doi:10.1006/game.1996.0026

Kenward, B., Hellmer, K., Winter, L. S., \& Eriksson, M. (2015). Four-year-olds' strategic allocation of resources: Attempts to elicit reciprocation correlate negatively with spontaneous helping. Cognition, 136, 1-8. doi:10.1016/ j.cognition.2014.11.035

Kinzler, K. D., Dupoux, E., \& Spelke, E. S. (2007). The native language of social cognition. Proceedings of the National Academy of Sciences, 104(30), 12577-12580. doi:10.1073/ pnas.0705345104

Lerner, M. J. (1974). The justice motive: "Equity" and "parity" among children. Journal of Personality and Social Psychology, 29(4), 539-550. doi:10.1037/h0036206

Liberman, Z., Howard, L. H., Vasquez, N. M., \& Woodward, A. L. (2018). Children's expectations about conventional and moral behaviors of ingroup and outgroup members. Journal of Experimental Child Psychology, 165, 7-18. doi:10.1016/ j.jecp.2017.03.003

Liu, B., Huang, Z., Xu, G., Jin, Y., Chen, Y., Li, X.,...Jing, J. (2016). Altruistic sharing behavior in children: Role of theory of mind and inhibitory control. Journal of Experimental Child Psychology, 141, 222-228. doi:10.1016/j.jecp.2015.09.010

Ma, H. K., \& Leung, M. C. (1991). Altruistic orientation in children: Construction and validation of the child altruism 
inventory. International Journal of Psychology, 26(6), 745759. doi:10.1080/00207599108247163

McAuliffe, K., \& Dunham, Y. (2017). Fairness overrides group bias in children's second-party punishment. Journal of Experimental Psychology: General, 146(4), 485-494. doi:10.1037/xge0000244

Misch, A., Over, H., \& Carpenter, M. (2016). I won't tell: Young children show loyalty to their group by keeping group secrets. Journal of Experimental Child Psychology, 142, 96106. doi:10.1016/j.jecp.2015.09.016

Miyake, A., Friedman, N. P., Emerson, M. J., Witzki, A. H., Howerter, A., \& Wager, T. D. (2000). The unity and diversity of executive functions and their contributions to complex "frontal lobe" tasks: A latent variable analysis. Cognitive Psychology, 41(1), 49-100. doi:10.1006/ cogp.1999.0734

Moore, C. (2009). Fairness in children's resource allocation depends on the recipient. Psychological Science, 20(8), 944948. doi:10.1111/j.1467-9280.2009.02378.x

Oh, S., \& Lewis, C. (2008). Korean preschoolers' advanced inhibitory control and its relation to other executive skills and mental state understanding. Child Development, 79(1), 80-99. doi:10.1111/j.1467-8624.2007.01112.x

Olson, K. R., \& Spelke, E. S. (2008). Foundations of cooperation in young children. Cognition, 108(1), 222-231. doi:10.1016/ j.cognition.2007.12.003

Oosterbeek, H., Sloof, R., \& Van De Kuilen, G. (2004). Cultural differences in ultimatum game experiments: Evidence from a meta-analysis. Experimental Economics, 7, 171-188. doi:10.1023/B:EXEC.0000026978.14316.74

Over, H. (2018). The influence of group membership on young children's prosocial behaviour. Current Opinion in Psychology, 20, 17-20. doi:10.1016/j.copsyc.2017.08.005

Paulus, M., Licata, M., Kristen, S., Thoermer, C., Woodward, A., \& Sodian, B. (2015). Social understanding and selfregulation predict pre-schoolers' sharing with friends and disliked peers: A longitudinal study. International Journal of Behavioral Development, 39(1), 53-64. doi: $10.1177 / 0165025414537923$

Renno, M. P., \& Shutts, K. (2015). Children's social category-based giving and its correlates: Expectations and preferences. Developmental Psychology, 51(4), 533-543. doi:10.1037/ a0038819

Rothbart, M. K., \& Derryberry, D. (1981). Development of individual differences in temperament. In M. E. Lamb \& A. L. Brown (Eds.), Advances in Developmental Psychology (Vol. 1, pp. 37-86). Hillsdale, NJ: Lawrence Erlbaum Associates.

Ryan, K., \& Bohlin, K. E. (1999). Building character in schools: Practical ways to bring moral instruction to life. Hoboken, NJ: Wiley.
Singer, T., \& Fehr, E. (2005). The neuroeconomics of mind reading and empathy. American Economic Review, 95(2), 340-345. doi: $10.1257 / 000282805774670103$

Smith, C. E., Blake, P. R., \& Harris, P. L. (2013). I should but i won't: Why young children endorse norms of fair sharing but do not follow them. Plos One, 8(3), 1-10. doi:10.1371/ annotation/4b9340db-455b-4e0d-86e5-b6783747111f

Tajfel, H., Billig, M. G., Bundy, R. P., \& Flament, C. (1971). Social categorization and intergroup behaviour. European Journal of Social Psychology, 1(2), 149-178. doi:10.1002/ ejsp.2420010202

Takagishi, H., Kameshima, S., Schug, J., Koizumi, M., \& Yamagishi, T. (2010). Theory of mind enhances preference for fairness. Journal of Experimental Child Psychology, 105(12), 130-137. doi:10.1016/j.jecp.2009.09.005

Takezawa, M., Gummerum, M., \& Keller, M. (2006). A stage for the rational tail of the emotional dog: Roles of moral reasoning in group decision making. Journal of Economic Psychology, 27(1), 117-139. doi:10.1016/j.joep.2005.06.012

Yu, J., Zhu, L., \& Leslie, A. M. (2016). Children's sharing behavior in mini dictator games: The role of in-group favoritism and theory of mind. Child Development, 87(6), 1747-1757. doi: $10.1111 /$ cdev. 12635

Walsh, F. (1988). The family in later life. The family life cycle: A framework for family therapy. New York: Gardner Press.

Wechsler, D. (1999). Wechsler abbreviated scale of intelligence WASI: Manual. San Antonio, TX: The Psychological Corporation.

Wong, M., \& Nunes, T. (2003). Hong Kong children's concept of distributive justice. Early Child Development and Care, 173(1), 119-129. doi:10.1080/0300443022000022477

Zelazo, P. D., \& Müller, U. (2011). Executive function in typical and atypical development. In U. Goswami (Ed.), The WileyBlackwell handbook of childhood cognitive development (2nd ed., pp. 574-603). Hoboken, NJ: Wiley-Blackwell.

\section{In Korean}

Bae, Y. J., \& Lim, J. Y. (2012). Factors affecting preschooler's prosocial behavior and cognitive problem-solving ability: Focusing on the parents' and preschooler's effortful control, and affectionate parenting behavior. Korean Journal of Child Studies, 33(3), 1-22. doi:10.5723/KJCS.2012.33.3.1

Byun, H. W., \& Sung, J. (2018). The effects of children's inhibitory control, temperament and teaching interaction on peer initiative. Korean Journal of Early Childhood Education, 38(1), 289-317. doi:10.18023/kjece.2018.38.1.012

Byun, H. W. (2017). The effects of children's inhibitory control, temperament and teacher-child interaction on peer initiative (Doctoral dissertation). Retrieved from http://www.riss.kr/ link?id=T14577679 
Cha, M. J., \& Song, H. J. (2015). The influence of in-group favoritism on 5 to 6-year-olds' resource-allocation decisions. Korean Journal of Cognitive Science, 26(2), 241-261.

Cheon, Y., \& Kim, H.-R. (2015). The effect of the type of resources on the children's resource allocation in the dictator game. The Korean Journal of Developmental Psychology, 28(1), 101116.

Choi, E. A., \& Song, H. N. (2013). Development of children's cool and hot executive function and its relationship to children's self-regulation. Korean Journal of Child Studies, 34(5), 99-114. doi:10.5723/KJCS.2013.34.5.99

Garolyn, P. E., \& Ha, Y. H. (2005). The effect of parents attachment, socioeconomic status, and perspective-taking on early adolescents' prosocial behavior toward parents and siblings. Korean Journal Psychological and Social Issues, 11(1), 43-57.

Han, J., \& Lee, J. (2017). The mediating effects of intelligence on the relationship between temperament and social competence in preschoolers. Journal of Cognitive Enhancement and Intervention. 8(1), 51-69.

Hahn, J. (2014). Choices and their determinants of college students in dictator games. Korean Journal of Economic Education, 21(2), 59-83.

Hong, S.-O. (2003). A study on the preference of young children's friends of the same sex according to their age and sex. The Korea Journal of Child Care and Education 34, 315-338.

Kang, C.-H., Kim, M.-O., Lee, J.-E., \& Lee, K.-E. (2007). Effects of philanthropy education on elementary school students in Korea: Analysis using a multiple convergence model. Korean Journal of Social Welfare, 59(4), 5-35.

Kim, H. J., \& Hong, S. O. (2011). The relationship between intelligence and executive function of young children. Journal of Future Early Childhood Education, 18(1), 99-116.

Kim, H.-S. (2012). The mediating efects of cognitive ability on the relationship between self regulation and prosocial behavior of preschooler. The Korea Association of Child Care and Education, 71, 203-221.

Kong, Y., \& Lim, J.-Y. (2011). Analysis of trends in research on executive function. The Korean Journal Child Education. 20(1), 61-75.

Park, H. W., Kwak, K. J., \& Park, K. B. (1996). K-WPPSI WORKSHOP (Basic). Seoul: Special Education.

Kwon, J., \& Park, Y. (2013). Effects of understanding of mind and empathy on children's prosocial behavior in the dictator game. The Korean Journal of Developmental Psychology, 26(3), 117-138.

Lee, Y. J. (2010). Development in nonverbal intelligence and executive function in 3-7 years old: Comparison between normal and attention problem children (Master's thesis). Retrieved from
http://www.riss.kr/link?id=T12322142

Moon, H. L. (2011). Relationship between interactive behavior and perception of friends around five-year-old children in friendship. Early Childhood Education Research \& Review, 15(5), 5-27.

No, G., Bak, H., An, J., \& Jeon, Y. (2016). Making use of the Wechsler intelligence scale in clinical \& educational settings: a guidebook. Seoul: Hakjisa.

Park, J. S., \& Park, Y. (2013). Developmental and gender differences in children's altruistic behaviors in the dictator game and the role of perspective-taking. Discourse and Policy in Social Science, 6(1). 167-186.

Park, J., \& Jin, K. (2020). Who should share? Preschoolers' judgments regarding the moral responsibility of ingroup and outgroup members toward "the poor". The Korean Journal of Developmental Psychology, 33(2), 69-85.

Park, H. W. (2001). Development of a short form of the Korean Wechsler preschool and primary scale of intelligence. Korean Journal of Child Studies, 22(2), 1-13.

Park, H. W., \& Lee, Y. (2013). Development of executive function in 3-7 year olds: Analyses by age and maternal employment. The Korean Journal of Developmental Psychology, 26(1), 137 155.

Park, S., \& Park, H. W. (2016). The relation between the performances in K-WPPSI-IV and executive control abilitiy. Journal of Cognitive Enhancement and Intervention, 7(1), 129-142.

Sung, H. R., Sung, E. H., Jang, Y. C., Jung, M. S., Park, H. W., Lee, H. J.,... You, Y. O. (2019). Developmental psychology. Seoul: Hakjisa.

Yeom, S., \& Lee, G. (2016). The relationship among children working memory, processing speed, and maladjustment behaviors. Journal of Cognitive Enhancement and Intervention, 7(1), 1-13.

Yoo, E. (1997). Justice distribution concept of children (Master's thesis). Retrieved from http://www.riss.kr/link?id=T4459000

\section{ORCID}

Hye-Weon Byun http://orcid.org/0000-0001-5558-5198

Jihyun Sung http://orcid.org/0000-0003-1149-6788

Received April 30, 2021

Revision received June 6, 2021

Accepted June 18, 2021 